\title{
SEJARAH PEMIKIRAN EKONOMI ISLAM
}

\author{
Oleh : Eka Murti Sari
}

\section{A. Pada Masa Rasulullah SAW}

Pemikiran Ekonomi Islam diawali sejak Rasulullah SAW dipilih sebagai seorang Rasul (utusan Allah). Rasulullah SAW mengeluarkan sejumlah kebijakan yang menyangkut berbagai hal yang berkaitan dengan masalah kemasyarakatan, selain masalah hukum (fiqh), politik (siyasah), juga masalah perniagaan atau ekonomi (muamalah).

Pemikiran Ekonomi Islam bersamaan muncul dengan diturunkannya Al Qur'an dan pada masa kehidupan Rasulullah pada akhir abad $6 \mathrm{M}$ hingga awal abad 7 M. kehidupan Rasulullah SAW dan umat Islam di masa Rasulullah merupakan teladan yang paling baik untuk implementasi Islam, termasuk pada bidang ekonomi.

Pada masa rasulullah kebijakan fiskal diterapkan oleh pemerintah dalam bidang anggaran belanja Negara dengan tujuan untuk menstabilkan perekonomian yang lebih baik dan laju pembangunan ekonomi yang diinginkan.

B. Pemikiran Ekonomi Islam Pada Masa Khulafaurrasyidin

\section{Masa Abu Bakar}

Pada masa kepemimpinan Abu Bakar mengalami berbagai masalah seperti kelompok murtad, nabi palsu, dan menentang pembayaran zakat. Terkait dengan hal tersebut Abu Bakar melakukan musyawarah dengan sahabatnya dan dia memutuskan untuk memusuhi kelompok tersebut yang dinamakan sebagai perang Riddah atau perang melawan kemurtadan.

Pada saat menjalankan pemerintahan dan perputaran ekonomi masyarakat Madinah, Abu Bakar sangat memperhatikan dengan teliti mengenai perhitungan zakat.

Adapun prinsip yang digunakan Abu Bakar dalam mendistribusikan harta baitul mal yaitu dengan prinsip sama rata, dengan memberikan jumlah yang sama kepada semua sahabat Rasulullah dan tidak membedakan satu sama lain. Sehingga pada masa Abu Bakar harta baitul Mal tidak pernah menumpuk dalam jangka waktu yang lama karena Abu Bakar langsung memberikan kepada seluruh Umat Muslim.

2. Masa Umar bin Khattab

Pada masa pemerintahan Umar ada beberapa kebijakan yang terkait dengan perekonomian umat muslim, yakni :
a. Pendirian Baitul Mal.
b. Pajak Kepemilikan Tanah
c. Zakat

3. Masa Utsman bin Affan

Utsman bin Affan pada masa pemerintahannya melakukan suatu langkah kebijakan yaitu dengan tidak mengambil gaji di kantornya. Sebaliknya, Utsman bin Affan meringankan beban pemerintah dalam sesuatu yang serius, dan Utsman 
menyimpan uangnya pada bendahara Negara. Hal ini ternyata menimbulkan kesalah pahaman dan kecekcokan dengan Abdullah bin Arqam yakni bendahara Baitul Mal.

Adapun kebijakan lain yang dilakukan Utsman bin Affan mengenai perekonomian yaitu dengan tetap mempertahankan pemeberian bantuan seperti dengan memberikan sejumlah uang kepada masyarakat yang berbeda-beda.

4. Masa Ali bin Abi Thalib

Ali bin Abi Thalib merupakan khalifah yang sederhana, Ali dengan ikhlas menarik dirinya dari daftar penerima bantuan Baitul Mal, bahkan yang lainnya mengatakan bahwa Ali memberikan 5000 dirham setiap tahunnya.

Pada masa Ali kebijakan yang perekonomian yang dilakukan pada masa pemerintahannya adalah dengan menetapkan pajak pada para pemilik hutan sebesar 4000 dirham dan member izin Abu Abbas, Gubernur Kufah, mengambil zakat terhadap sayuran segar yang akan digunakan sebagai bumbu masakan. Ali juga mempunyai prinsip bahwa pemerataan distribusi uang rakyat yang sesuai dengan kapasitasnya. Adapun keistimewaan khalifah Ali pada masa pemerintahannya adalah masalah administrasi umum dan masalah masalah yang berkaitan dengan tersusun secara rapi.

C. Pemikiran Ekonomi Islam Masa Dinasti Abbasiyah

Pada masa Dinasti Abbasiyyah pemikiran ekonomi Islam terlihat pada dua apek, yaitu pranata ekonomi dan pemikiran ekonomi.beberapa pranata yang muncul pada masa dinasti abbasiyyah adalah pertanian, perdagangan, dan industry. Adapun pemikiran ekonomi beberpa ulama yang mepunyai pemikiran mengenai Ekonomi Islam pada masa itu ialah Abu Yusuf, Al-Syabani, Yahya bin Umar, Abu Ubaid, Al- Mawardi, dan Al- Ghazali.

D. Pemikiran Ekonomi Al Ghazali

Pada posisi Al Ghazali dalam sejarah pemikiran ekonomi Islam masuk pada fase II. Dalam fase II ini dilatarbelakangi oleh korupsi, serta meluasnya kemiskinan dan kaya, meskipun secara umum kondisi perekonomian Umat Islam berada pada taraf kemakmuran.

E. Pemikiran Ekonomi Islam Masa Kontemporer

Pemikiran ekonomi Islam pada masa kontemporer yaitu Muhammad Abdul Mannan. Pada tahun 1970, ekonomi Islam baru saja mencari formulanya, sementara Muhammad Abdul Mannan berhasil menurunkan mengenai kerangka dan cirri cirri khusus ekonomi Islam. Perlu diakui bahwa saat itu yang dimaksud ekonomi Islam adalah fikih muamalah. 